\title{
Solid Biofuels Scenarios from Rural Agricultural and Forestry Residues for Mexican Industrial SMEs
}

\author{
Oscar Ruíz-Carmona (D), Jorge M. Islas-Samperio * (D), Lourdes Larrondo-Posadas (D), Fabio Manzini, \\ Genice K. Grande-Acosta (D) and Christian Álvarez-Escobedo
}

check for updates

Citation: Ruíz-Carmona, O.; Islas-Samperio, J.M.;

Larrondo-Posadas, L.; Manzini, F.; Grande-Acosta, G.K.;

Álvarez-Escobedo, C. Solid Biofuels Scenarios from Rural Agricultural and Forestry Residues for Mexican Industrial SMEs. Energies 2021, 14, 6560. https://doi.org/10.3390/ en14206560

Academic Editor: Attilio Converti

Received: 7 September 2021

Accepted: 4 October 2021

Published: 12 October 2021

Publisher's Note: MDPI stays neutral with regard to jurisdictional claims in published maps and institutional affiliations.

Copyright: (c) 2021 by the authors. Licensee MDPI, Basel, Switzerland. This article is an open access article distributed under the terms and conditions of the Creative Commons Attribution (CC BY) license (https:/ / creativecommons.org/licenses/by/ $4.0 /)$.
Instituto de Energías Renovables, Universidad Nacional Autónoma de México, Priv. Xochicalco S/N, Col. Centro, Temixco 62580, Morelos, Mexico; ocarmona@xenercoenergy.com (O.R.-C.);

lourdes.larrondo10@gmail.com (L.L.-P.); fmp@ier.unam.mx (F.M.); gkga@ier.unam.mx (G.K.G.-A.); alesc@ier.unam.mx (C.Á.-E.)

* Correspondence: jis@ier.unam.mx; Tel.: +52-(55)-5622-9791

Abstract: In Mexico, as in the rest of the world, the industry sector is frequently highly dependent on fossil fuels; in addition, energy transformation processes are not very efficient and scarcely oriented towards climate change mitigation. Given these facts, solid biofuels (SBFs) from agricultural and forestry residues from rural areas may represent an alternative that contributes to the decarbonization of the industrial sector, especially in Small- and Medium-Sized Enterprises (SMEs). From an economic and climate change mitigation perspective, this study evaluates harnessing SBFs in SMEs related to lime, bricks, dairy products, craft beer, and artisanal mezcal (a well-known Mexican distilled alcoholic beverage), products mainly manufactured in rural areas of Mexico. For each of these SMEs, we constructed two energy consumption scenarios that span from 2018 to 2050. On the one hand, a baseline scenario (BS) that reflects the behaviour of historical energy consumption in Mexico and, on the other hand, an alternative scenario (AS) that proposes the use of SBFs with modern and efficient technologies and sustainable inputs of agricultural and forestry residues originated mainly from rural areas. According to our results, a comparison between the two scenarios reveals that two out of five SMEs industrial niches studied, appear with mitigation costs in the AS namely brick kilns, and limekilns SMEs that have mitigation costs of 9.99 and $19.74 \mathrm{USD} / \mathrm{tCO}_{2 \mathrm{e}}$, respectively, primarily due to the high investment cost of the new MK2 kilns and the relatively high cost of pellets, respectively. Since these niches have high mitigation potentials $\left(7.77 \mathrm{MtCO}_{2 \mathrm{e}}\right.$ for brick kilns and $2.83 \mathrm{MtCO}_{2 \mathrm{e}}$ for limekilns), their implementation requires adequate incentives and financing. On the contrary, the dairy, craft beer, and mezcal SMEs niches have negative mitigation costs $(-14.30,-10.68,-0.98)$ $\mathrm{USD} / \mathrm{tCO}_{2 \mathrm{e}}$, mainly due to the high savings in the cost of fossil fuels and their materialization, especially for the mezcal niche which has a mitigation potential of $2.97 \mathrm{MtCO}_{2 \mathrm{e}}$, requires only an adequate regulatory and normative framework. We conclude that using commercial SBFs (pellets, briquettes, and traditional firewood) in SMEs niches contribute to generating formal markets with adequate distribution channels, both for SBFs and sustainable residual biomass inputs (residual firewood, agave bagasse, and spent barley grain). This alternative scenario also promotes the creation of green jobs in agricultural and forestry areas, adding an economic value to residual biomass inputs not previously considered and contributing to the social development of rural areas.

Keywords: solid biofuels (SBFs); industrial SMEs niches; scenarios; cost-benefit analysis; agricultural and forestry residues

\section{Introduction}

According to [1], in 2018, the global industrial sector consumed 252 EJ, representing $38.5 \%$ of the global energy consumption; by 2050, it is expected to increase to $334.1 \mathrm{EJ}$, $34.8 \%$ of global consumption. This industry contributed $21.7 \mathrm{GtCO}_{2 \mathrm{e}}$, accounting for $15.06 \%$ of the global GHG emissions [2]. Besides, coal consumption accounted for $26.7 \%$, liquid fuels and natural gas for $26.1 \%$, electricity $15.4 \%$, while renewables contributed only 
$8.7 \%$ of global industrial energy consumption. By 2050 , liquid fuels may represent $25.9 \%$, coal $24.4 \%$, natural gas $23.7 \%$, electricity $16.2 \%$ and renewable energies $9.8 \%$ of global industrial energy consumption [1]. Industrial heat requirements account for approximately $75 \%$ of its end-use energy demand worldwide, where $50 \%$ are low-temperature $\left(<150{ }^{\circ} \mathrm{C}\right)$ and average temperature processes $\left(150{ }^{\circ} \mathrm{C}\right.$ at $\left.400{ }^{\circ} \mathrm{C}\right)$ [3]. According to report [4], in 2018 , the industrial sector consumed $8.9 \mathrm{EJ}$ of SBFs, equivalent to $13.5 \%$ of world biomass consumption and 3.5\% of global industrial energy consumption. Modern SBFs (pellets and woodchips) contributed with $99.5 \%$ [5]. In addition, there are countries and world regions that consume SBFs in significant percentages in the industrial sector, among them are the following:

(a) In the European Union (EU28), the use of solid biomass for combined heat and power (CHP) and heat generation accounted in the industry for $8.37 \%$ of renewable energy use in that region, making it the most significant renewable energy source [5]. Likewise, the industrial use of pellets grew by $14.5 \%$ in 2018 compared to 2017, driven by the United Kingdom and the Netherlands consumption [6].

(b) In the United States, the industry consumes most of its SBFs from wood and wood residues; its biggest consumers are manufacturers of wood and paper products and use their waste to generate heat and electricity. In 2019, wood and wood waste accounted for approximately $5.6 \%$ of end-use energy consumption in this country [7].

(c) In China, the SBF's industrial sector had a 4.2\% (4.11 EJ) share of final energy consumption in $2018[8,9]$.

(d) In Finland, in 2018, SBFs in industry supplied $43 \%$ of the final energy consumption. Industries consuming solid biofuels include pulp and paper, wood and wood products, chemicals and petrochemicals, food and tobacco, non-ferrous minerals, machinery, iron, and steel $[8,9]$.

In addition to the residues mentioned above for solid biofuels production, it is worth mentioning that citrus cultivation is one of the largest worldwide. Its annual production is 124.3 million tonnes, of which $40-60 \%$ are citrus wastes that can be processed to obtain recycled materials [10]. In Mexico, citrus peels have low potential but are an appealing option for regional agro-industries that currently use these residues to replace fuel oil [11].

Citrus peel residues have, however, high potential in terms of biorefining [12], and are a promising and sustainable option as their production does not compete with food or animal feed $[13,14]$. These residues can be used to generate bioelectricity and produce liquid biofuels [10], biogas production [14], heat and power generation-CHP-[15], and can be used for direct combustion [16] or in the form of pellets [11,15].

The above examples show how modern SBFs, through the adoption of cleaner and lowcarbon technologies, can be used mainly for heat generation in the industrial sector. The forms of solid biofuels used in the industrial sector vary, including unprocessed firewood, wood chips, bagasse, and densified solid biofuels, including briquettes and pellets [17-19]. Studies such as the one from [20] argue that due to their essential environmental and social benefits, agricultural residues (AR), forest residues (FR), or agro-industrial residues (AIR) are biomass inputs, and the industrial sector should use them as solid biofuels. Likewise, Ref. [21] proposes that such residues can be converted into densified SBFs to broaden their potential applications and improve utilization efficiency.

However, several barriers hamper the utilization of SBFs in the industrial sector [22]; among them are: (a) infrastructure, which includes the need for adequate spaces for conservation and storage of these fuels [23]; (b) financial, such as the investment cost required to implement modern technologies, and projects' profitability; (c) lack of established markets to mitigate risks associated with product quality, delivery and price, which can be solved by creating formal market centres for SBFs with established rules [18]; (d) SBFs distribution channels from [24] and; (e) lack of incentives to offset the higher cost of SBFs relative to that of fossil fuels. Together, these barriers have contributed to waste enormous amounts of residual biomass [18] annually. Finally, the SBFs require: the development of regulations and public policies for the sustainable management of biomass, the use of agricultural and 
forestry residues, the reduction of their environmental impact, and the development of value chains $[25,26]$. Despite these barriers, the United Nations Industrial Development Organization [27] carried out a long-term projection proposing it is possible to sustainably supply 50 EJ of biomass from plantations and residues for industrial applications, given that there are significant quantities of agricultural and wood processing residues of the order of $100 \mathrm{EJ} /$ year.

At global and regional levels, prospective studies found in the world literature on SBFs harnessing the industrial sector usually do not specify the niches studied, the origin of the input biomass, or the shape of solid biofuels. One exemption constitutes a scenario published by [26] in which they propose that biomass injection in blast furnaces should replace pulverised coal and other fossil sources in the steel industry niche in Sweden from 2007 to 2030. In Mexico, there are several prospective studies of industrial use of SBFs; however, these studies focus only on one specific industrial niche: sawdust as solid fuel in sawmill incinerators [28], sugarcane bagasse as fuel for cogeneration in sugar mills in [29], charcoal as a partial substitute for coke in the steel industry in sintering and blast-baking processes [30-32]. In addition, various authors have proposed SBF's substitution of fossil fuels in the industrial sector without specifying the application niche $[11,31,33,34]$.

This article develops scenarios that consider technical, economic, and environmental implications for the sustainable use of SMEs in various niches of the industrial sector in Mexico. Moreover, in these scenarios, we emphasize the application to Small and Medium Enterprises (SMEs), modern SMEs harnessing technologies for both traditional (firewood) and modern (pellets and briquettes) SMEs. Additionally, we consider using existing and currently non-valorised residual biomass in rural areas for SMEs production. This apparent abandonment is due to the lack of prospective studies with this width; most are nationallevel studies that do not integrate these elements. On the other hand, our scenarios may be of great interest to other countries with similar biomass residues potentials who wish to incorporate the modern use of SMEs in the industrial sector and contribute to climate change mitigation and social development in the rural sector.

In this study, we consider the fact that most of the Mexican industrial establishments are SMEs, with 4.9 million representing 99.8\% [35], which in general use fossil fuels with low-efficiency technologies for their thermal processes [36], negatively impacting the environment with their GHG emissions. The importance of this prospective study lies in the fact that we show that there are some niches in this universe of enterprises where sustainable use of SBFs with modern technologies could be proposed. We studied some niches that harness SBFs as an option to modernise, become more efficient and competitive, and thus reduce their GHG emissions and their environmental impact. The primary source can be residual biomass from which new value chains in the agricultural, forestry and agro-industrial sectors could also be detonated, leading to social development and jobs in rural Mexico, commonly characterised by the general poverty of its inhabitants.

The reference niches analysed in this article correspond to that of the SMEs dedicated to manufacturing bricks, dairy products, craft beer, and artisanal mezcal (a well-known distilled alcoholic beverage from Mexico, made from a variety of agave cacti). Next, we evaluate each niche's specific end-use energy demand, corresponding to the processes, technologies, and energy used to evaluate later a traditional SBFs more efficient use or a partial or total replacement by modern SBFs. The above procedure allows us to explore the use of agro-industry residual biomass generated in the industrial niche itself in rural agricultural areas or pellets from forest residues in the rural sector. In addition, the implementation of efficient commercial technologies to use commercial SBFs as an energy source, besides carrying out an economic and emission reduction evaluation of greenhouse gases and compounds (CGHG), allow us to identify the viability or challenges posed by the modern use of SBFs in the studied SMEs niches.

After the above introduction, this paper is organized as follows: Section 2 describes the current situation of SBFs in the Mexican industrial sector and the need to use them in SMEs in industrial niches. Section 3 presents the general methodology to construct 
scenarios starting from a model that evaluates the future thermal energy demand in each industrial SME niche. Section 4 introduces the cost-benefit and mitigation models to estimate the economic viability and GHG emission reductions in the industrial SMEs sector due to SBFs. Section 5 presents the construction of base scenarios of the studied niches and their description in terms of technology, fuels, and costs. Section 6 explains the construction of alternative scenarios considering efficient and appropriate technologies and SBFs' substitution of fossil fuels. Section 7 presents the energy, environmental and economic results. Finally, Section 8 presents the conclusions.

\section{Current Situation of the Use of SBFs in the Mexican Industrial Sector}

According to the National Energy Balance [37], in 2018, the participation of SBFs in Mexico in final energy consumption represented $5.8 \%$ of the total (5284 PJ), which makes SBFs the leading renewable energy for final consumption in Mexico. Sugarcane bagasse represented $1.1 \%$ and fuelwood $4.7 \%$ of total SBFs consumption. Most of the fuelwood is burned in traditional technologies for residential cooking, while sugarcane bagasse is burned in all country's sugar mills since decades ago to supply most of the power and process heat this industry needs. Therefore, using bagasse, fueloil consumption has reduced in sugar mills but still represented 22\% in 2018 [38]. Sugarcane bagasse is also currently used to improve energy efficiency in sugar manufacturing [39].

However, there is literature evidence that not all uses of SBFs in the Mexican industrial sector are reported in the National Energy Balance. This is difficult to quantify and document fully. For example, Refs. [40,41] mentions chips and/or bagasse in manufacturing industries such as cigarettes, tequila, soluble coffee, and cement. In addition, SBFs are used in distilleries, palm oil processors, and blacksmithing.

Specifically, Ref. [42] mentions that cellulosic pulp and paper industries burn their wood wastes to generate process heat and power. Furthermore, Ref. [43] reports that in a Tequila distillery, the use of agave bagasse mixed with other biofuels, such as wood chips, fulfils process heat requirements. The same author reports that coffee bagasse is used as SBF to generate $50 \%$ of the needed steam for soluble coffee manufacture. In addition, Godoy (2020) mentions wood waste burn for electricity generation in a sawmill. Considering these uses of SBFs, which in most cases employ agricultural and forestry waste biomass from rural areas, reported in the industrial niches just mentioned, it is evident that in Mexico and other countries with similar situations, there is a need to carry out prospective studies of SBFs from waste biomass from rural areas, for use in SMEs in industrial niches.

\section{General Methodology}

We applied the scenario building methodology to estimate the technical and economic feasibilities and GHG emission reductions in the industrial SMEs sector due to the use of SBFs fabricated from residual biomass of agricultural and forestry activities in rural areas. The addressed methodology consists in developing a general model that evaluates the future demand for thermal energy in each industrial SMEs niche with a long-term horizon of 32 years, taking 2018 as the base year and ending the study period in 2050.

This model systematically relates the demand for specific thermal energy to fabricate various products identified in the SMEs' niches under study (activity level of the niche), considering technological, economic, and GHG emission factors. We apply the end-use approach to estimate each niche's energy demand, quantifying the energy resources consumed to obtain a product. The equation applied to estimate the niche's energy demand is:

$$
E=A L \times I
$$

where $E$ is the thermal energy demand of the industrial niche, $A L$ is the average activity level of the niche, and I is the specific energy consumption relative to the process. This last parameter, defined as the thermal energy consumption per product generated, is an input parameter given in each scenario since it is a characteristic of each subsector and depending on the end-use technologies. Table 1 shows the specific activity levels, production in 2018, 
units, average annual growth rates (AAGR), and data sources of the industrial niches included in this study.

Table 1. Activity levels, production, units, AAGR, and information sources in the prospective period 2019-2050. Data needed for BSs construction of studied niches.

\begin{tabular}{|c|c|c|c|c|c|}
\hline Niche & Activity Level & $\begin{array}{l}\text { Production } \\
\quad(2018)\end{array}$ & Units & $\begin{array}{c}\text { AAGR } \\
(2018-2050)\end{array}$ & $\begin{array}{l}\text { Information Source for } \\
2018 \text { Data and Historical } \\
\text { Trends from AAGR }\end{array}$ \\
\hline Brick kilns & $\begin{array}{l}\text { Bricks production } \\
\text { and others }\end{array}$ & 225,923 & $\begin{array}{l}\text { Thousand } \\
\text { pieces }\end{array}$ & $-1.3 \%$ & [44] \\
\hline Limekilns & Lime production & 970,515 & tons & $2.1 \%$ & [44] \\
\hline \multirow[t]{2}{*}{ Dairy companies } & $\begin{array}{l}\text { Industrialized milk } \\
\text { production }\end{array}$ & 30,193 & thousand litres & $-2.9 \%$ & [44] \\
\hline & $\begin{array}{l}\text { Dairy products (cheeses) } \\
\text { production }\end{array}$ & 55,519 & tons & $6.0 \%$ & [44] \\
\hline Craft breweries & Craft beer production & 189,250 & hectolitres & $2.9 \%$ & [45] \\
\hline Artisanal Mezcal & Mezcal production & 5089 & thousand litres & $5.9 \%$ & [46] \\
\hline
\end{tabular}

Source: Own elaboration.

For long-term projections, up to the year 2050, the activity levels of each niche were established based on the analysis of historical trends. In specific cases, we calculate $A L$ values through linear regression, explaining the relationship between the activity level of each SME niche with sectoral GDP. The energy sources participating in each niche were defined based on identified references, case studies, analysis of retrieved statistical information, and heat power values of the corresponding fuels. All data are referenced for each niche studied.

\section{Cost-Benefit Model and Mitigation Model}

We estimate the costs and economic benefits of the analysed options for each of the selected SMEs niches by comparing an alternative scenario (AS) that uses SBFs to the baseline scenario (BS) that applies current technologies and fuels; we use the following equation according to $[47,48]$ :

$$
C B_{\mathrm{AS}-\mathrm{BS}}=C I_{\mathrm{AS}-\mathrm{BS}}+C O \& M_{\mathrm{AS}-\mathrm{BS}}+C E_{\mathrm{AS}-\mathrm{BS}}
$$

where:

$$
\begin{aligned}
& C B_{\text {AS-BS }}=\text { Overall cost-benefit of implementing SBFs in a SME niche. All monetary } \\
& C I_{\mathrm{AS}-\mathrm{BS}}=\text { mitigation option in the AS using SBF in the SME niche, and the present } \\
& \text { Algebraic difference between the present value Operation and } \\
& C O \& M_{\mathrm{AS}-\mathrm{BS}}=\text { Maintenance }(\mathrm{O} \& \mathrm{M}) \text { costs of the mitigation option in the AS using SBFs } \\
& C E_{\mathrm{AS}-\mathrm{BS}}=\text { mitigation option in the AS using SBFs in the SME niche, and the present } \\
& C I_{\mathrm{AS}-\mathrm{BS}}=\sum_{a=1}^{p} \frac{C I_{(\mathrm{AS}-\mathrm{BS}) a}}{(1+d)^{a}}
\end{aligned}
$$

where: 


$$
\begin{aligned}
& C I_{(\mathrm{AS}-\mathrm{BS}) a}=\text { Algebraic difference of the investment costs occurring in year } a \text { due to }
\end{aligned}
$$

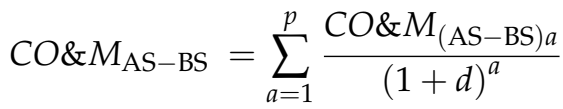

where:

$$
C O \& M_{(A S-B S) a}=
$$

Algebraic difference of the cumulative annual O\&M costs due to SBFs implementation in a SME niche in the AS, and the cumulative annual O\&M costs in the BS, during the analysis period.

$$
C E_{\mathrm{AS}-\mathrm{BS}}=\sum_{a=1}^{p} \frac{C E_{(\mathrm{AS}-\mathrm{BS}) a}}{(1+d)^{a}}
$$

where:

$$
\begin{aligned}
C E_{(A S-B S) a}= & \begin{array}{l}
\text { Algebraic difference between the annual cumulated costs during the } \\
\text { analysis period of using SBFs in a SME niche in the AS, and the annual } \\
\text { cumulated energy costs in the BS. }
\end{array}
\end{aligned}
$$

Once the overall cost-benefit is calculated in the present value of using SBFs in a SME niche in the AS, then we can calculate its mitigation cost applying Equation (6), this is, with this equation we obtain the unit cost of mitigating one ton of $\mathrm{CO}_{2 \mathrm{e}}$ in each studied niche throughout the analysis period.

$$
C M_{(\mathrm{AS}-\mathrm{BS})}=\frac{C B_{(\mathrm{AS}-\mathrm{BS})}}{G E I_{(\mathrm{AS}-\mathrm{BS})}}
$$

where:

$$
\begin{aligned}
& C B_{(\mathrm{AS}-\mathrm{BS})}=\begin{array}{l}
\text { Cost-benefit in present value of the SBFs implementation in the AS of the } \\
\text { SMEs niche related to the BS, from Equation (2). } \\
\text { Total avoided GHG emissions due to SBFs in the AS of the SMEs niche } \\
\text { related to the BS. See the following equation: }
\end{array} \\
& \qquad G E I_{(\mathrm{AS}-\mathrm{BS})}=\sum_{f=1}^{n} A_{(\mathrm{AS}-\mathrm{BS}) f} * E_{f}
\end{aligned}
$$

where:

$$
\begin{aligned}
& A_{(\text {AS-BS }) f}= \begin{array}{l}
\text { Total energy avoided by fuel } f \text { used in the BS during the analysis period, } \\
\text { due to the implementation of SBFs in the AS of the studied SMEs niche. } \\
\text { GHG emission factor from the energy source } f \text { in terms of } \mathrm{CO}_{2 \mathrm{e}} \text { in the BS. }
\end{array} \\
& \text { Table S2 in the Supplementary Material shows the GHG emission factors } \\
& \text { for fuelwood and fossil fuels used in the BS. SBFs are carbon neutral in } \\
& \text { the AS because they are sustainably produced exclusively from } \\
& \text { agricultural and forestry residues. }
\end{aligned}
$$

\section{Reference Year and Construction of the Baseline Scenario}

Because our model requires input data for a base year for each niche and energy use, we selected 2018 as the reference year, considering that there is recent and reliable information for this year, derived from various official sources mentioned below; also, in this year, economic stability prevailed in Mexico, therefore, the economic data used is more reliable. We feed the model with diverse input data such as MSE niche production and its growth rates, SME niche-specific energy consumption, fuel consumption structure by SME niche, calorific value, emission factors, and currency exchange rate. The data on the fuel consumption structure per niche in the reference year are necessary to calculate the future baseline of the niche of the fuel used to produce the required thermal energy to establish a reference time horizon (period of analysis); this allows to evaluate an alternative scenario in the short, medium, and long term of SBFs use in the SME niches considered. 
Based on current and historical information collected from public information sources, we determined the production levels in the reference year and the average annual growth rates (AAGR) (see Table 1). Considering the historical trends in the 2007-2018 period, we estimated the activity levels for the prospective period from 2019 to 2050 in the five analysed niches of SMEs of the Mexican Industrial sector: artisanal brick kilns, limekilns, dairy companies, craft breweries, and artisanal mezcal.

According to Equation (1), we estimated the baseline power requirements for each SME niche, by calculating the value of the specific energy consumption value in the prospective period. First, we assumed that the specific energy consumption of the technology used or, if applicable, of the different technologies used in the BS of the SMEs niche maintain the value; if more than one technology is used, we employ the current values found in the technical literature. To explain our approaches, the following description of each SME niche studied provides the data used to estimate the energy consumption in the BS according to the technology used or, where appropriate, to the different technologies used in each niche.

- $\quad$ Brick kilns

These SMEs produce non-refractory bricks, tiles, and clay tiles [49]. Currently, bricks are cooked in ovens for two to three days at a temperature between 800 and $1300{ }^{\circ} \mathrm{C}$ [50]. There are about 17,000 artisanal brick kilns in Mexico, primarily located in the central and central-western regions of the country [51]. Current brick kilns are mostly traditional fixed and traditional campaign types, representing $89 \%$ and $10 \%$ of the national production (NP). There are few horizontal multi-chamber kilns ( $0.9 \%$ of NP) and only $0.1 \%$ of MK2 efficient type kilns [51]. The specific energy consumption of the mentioned kilns per unit mass of bricks is: for the campaign type $4.2 \mathrm{MJ} / \mathrm{kg}$, for the fixed type $4 \mathrm{MJ} / \mathrm{kg}$, for the horizontal multi-chamber type $2.37 \mathrm{MJ} / \mathrm{kg}$, and for the MK2 type $2.7 \mathrm{MJ} / \mathrm{kg}[51,52]$. Therefore, we consider an average weight of $3.4 \mathrm{~kg}$ per piece based on data published by [53]. Moreover, we consider an average production capacity of 12,500 bricks in the campaign kiln, 32,500 pieces in the fixed kiln, 10,000 pieces in the horizontal multi-chamber kiln, and 7500 pieces in the MK2 type kiln [51]. We also consider an average of 15 batch burnings per kiln per year, which comes from the average number of burnings per year in brick kilns in 17 of the 33 Mexican states [51]. During the brick burning, the following fuels are used: wood (79\%), oils and waste (8\% each), and plastics (5\%) [54]. This same consumption structure is considered for all kiln types and in the GHGs estimation. The investment and O\&M costs of the brick kilns can be found in Table 2.

Table 2. Economic assumptions of brick kilns.

\begin{tabular}{cccccc}
\hline Kiln & Concept & Year & Cost & Units & Reference \\
\hline \multirow{4}{*}{ MK2 } & Investment & 2012 & $10,700.00$ & USD & {$[55]$} \\
& Operation & 2018 & 5.04 & USD/Thousand & {$[49]$} \\
& Maintenance & 2018 & 0.06 & USD/Thousand & {$[49]$} \\
\hline \multirow{4}{*}{ Traditional } & Investment & 2018 & $72,067.90$ & USD & {$[49]$} \\
& Operation & 2018 & 5.04 & USD/Thousand & {$[49]$} \\
& Maintenance & 2018 & 0.30 & USD/Thousand & {$[49]$} \\
\hline \multirow{2}{*}{ Horizontal } & Investment & 2018 & $120,113.16$ & USD & {$[49]$} \\
multi-chamber & Operation & 2018 & 52.83 & USD/Thousand & {$[49]$} \\
& Maintenance & 2018 & 0.50 & USD/Thousand & {$[49]$} \\
\hline
\end{tabular}

Source: Own elaboration from references data.

Regarding the use of firewood, around a third of the producers affirm that the firewood suppliers have a licence to exploit the resource, but most brick producers do not know the origin of their firewood [32,56]. Moreover, according to [49], there is a high probability that the artisanal brick industry may be a cause of deforestation in the surroundings of the production sites. Consequently, to calculate greenhouse compounds and greenhouse gas (CGHG) emissions from firewood, we assumed a non-renewability factor of $34 \%$ in the 
corresponding BS [57]. Therefore, the firewood consumption in the BS has a GHG emission factor different from zero (see Table S2 in the Supplementary Material).

\section{- Limekilns}

These SMEs generate several by-products of lime: quicklime, slaked lime, hydrated lime, lime for specific uses (agricultural, metallurgical, steel and chemical), and other products based on non-metallic minerals (dolomite and calcium carbonate) [46]. Lime is produced by calcination of limestone and/or ground dolomite, by direct exposure to fire in ovens for $18 \mathrm{~h}$ at a temperature between $1600{ }^{\circ} \mathrm{C}$ and $1700{ }^{\circ} \mathrm{C}$; at this stage, rocks subjected to calcination emit $\mathrm{CO}_{2}$ and produce calcium oxide [58-60].

From the information processing of 27 limekilns that reported their process fuel consumption in their Annual Operation Cards of the Ministry of the Environment and Natural Resources, we obtained a specific consumption of 2.1 GJ per ton of lime in the calcination process.

We also obtained an average share of fuels in which dry gas represents $75 \%$, fuel oil $6 \%$, petroleum coke 9\%, and diesel and LPG with less than 1\% [46]. We use this share to estimate this niche's energy demand and GHG emissions. Therefore, for our estimate of the baseline energy requirements of this industrial niche, both the specific consumption and the fuel consumption structure are considered to remain the same in the prospective period to estimate the baseline energy requirements of this industrial niche.

\section{- Artisanal Mezcal}

These SMEs produce mezcal, artisanal mezcal well-known distilled alcoholic beverage made from a variety of agave cacti; it can be either, artisanal mezcal or ancestral mezcal, depending on the degree of modernization of the manufacturing process and the variety of agave used [61]. The agave hearts (obtained after cutting off the outer thorny leaves) are cooked in stone ovens for three days, in which they absorb earth, wood, and smoke flavours. The cooked agave hearts are then crushed, combined with water, and allowed to ferment; then, a distillation process is carried out by boiling the mixture allowing alcohols to vaporize and subsequently condensed. In this niche, we consider two distillations to obtain the final product [62]. To estimate the energy demand of this niche, we made the following assumptions: specific consumption of $10 \mathrm{~kg}$ of firewood to produce 1 litre of mezcal [63], calorific value of firewood of $14.49 \mathrm{GJ} / \mathrm{t}$ [64], and mezcal production quantified in litres according to [48]. The firewood used for the cooking and distillation processes is purchased or collected from forest land, which lacks a sustainability certificate for its use [65], therefore, we used a non-renewability factor of 34\% in the BS to calculate GHG emissions from firewood [57].

- Dairy products

Micro, small and medium-sized dairy companies process milk and produce artisanal cheeses [46]. In order to eliminate pathogens, pasteurisation is performed by heating milk up to $63{ }^{\circ} \mathrm{C}$ for $30 \mathrm{~min}$ (low pasteurization) or $72{ }^{\circ} \mathrm{C}$ for $15 \mathrm{~s}$ (average pasteurization) [66]. In addition, heat is needed in this niche for cheese manufacture by heating milk to a temperature higher than $70{ }^{\circ} \mathrm{C}$ for whey separation [67]. Both heating processes are generally performed with a burner fuelled by LPG [46]; therefore, we consider LPG for the BS's energy and GHG emissions calculations. According to [68] are two types of dairy plants, simple and complex; depending on their modernization degree, they represent $94 \%$ and $6 \%$ of the total number of dairy plants, respectively. We are assuming the same structure during all the prospective periods. Table 3 shows the specific consumption values for this niche, which we assume are constant in the prospective period.

\section{- Craft breweries:}

According to the Mexican Association of Craft Brewers, there are currently $939 \mathrm{craft}$ breweries that produce a range of craft beer varieties. Inputs commonly used for the production of craft beer are water, malted grain (barley, rice, corn), hops, and yeast, which generate large amounts of spent grain as a by-product $[69,70]$ with a moisture content that 
ranges between 50 and 80\% [70]. Heat is needed to keep wort at a temperature between 65 and $68{ }^{\circ} \mathrm{C}$ for 45 to $60 \mathrm{~min}$ in the mashing process, and later, more heat is needed to keep wort at boiling point $\left(100{ }^{\circ} \mathrm{C}\right)$ for 60 to $90 \mathrm{~min}$ in the brewing process [71]. We estimated the specific energy consumption of $170.56 \mathrm{MJ} / \mathrm{hl}$ of craft beer based on the energy consumption of the national beer industry [37].

Table 3. Specific consumption for two types of plants in the SMEs niche of the dairy industry.

\begin{tabular}{cccc}
\hline Guy & Process & Indicator & Reference \\
\hline \multirow{2}{*}{ Simple plants } & Pasteurization & $180 \mathrm{MJ} / \mathrm{t}$ of processed milk & {$[68]$} \\
& $\begin{array}{c}\text { Cheese and yogurt } \\
\text { production }\end{array}$ & $180 \mathrm{MJ} / \mathrm{t}$ of processed cheese & {$[68]$} \\
Complex plants & Pasteurization & $250 \mathrm{MJ} / \mathrm{t}$ of processed milk & {$[68]$} \\
& $\begin{array}{c}\text { Cheese and yogurt } \\
\text { production }\end{array}$ & $450 \mathrm{MJ} / \mathrm{t}$ of processed cheese & {$[68]$} \\
\hline
\end{tabular}

Source: Own elaboration.

To estimate the energy requirements of craft breweries and their corresponding GHG emissions in the BS, we chose as reference fuels those most frequently used in the large brewing industry, which have the following shares: LPG $62.16 \%$, dry gas $28.07 \%$, fuel oil $9.41 \%$ and diesel $0.36 \%$ [37]. Although the annual production of craft breweries is less than $2000 \mathrm{hl}$, we assumed that the fuel consumption of traditional breweries has the same shares.

\section{Construction of the Alternative Scenario}

We built an alternative scenario based on the assumption of sustainable production and use of SBFs, considering that the fabrication of SBFs is sustainable due to residual biomass reuse, and that this biomass originally comes from agricultural and forestry activities in rural areas. Furthermore, we assume the same production levels as the BS, evaluating fuel substitutions and adjustments of end-use technologies.

In the niche of brick kilns, we propose replacing campaign traditional type kilns and fixed kilns with MK2 type kilns, which have much lower specific energy consumption. We propose a complete substitution by the year 2036. Furthermore, we assume that all needed SBFs in this niche will be residual, so all $\mathrm{CO}_{2}$ emissions are considered neutral. Additionally, after the year 2036, we will stop burning plastics and other hydrocarbons in all brick kilns. Assuming an average annual MK2 kilns diffusion rate of $8.1 \%$ by 2036 , there will be 36,611 new MK2 kilns.

In the limekilns niche, we propose replacing current fossil fuels with wood pellets fabricated with forestry residues and burned in existing boilers [72]. We consider a calorific value for wood pellets of $17 \mathrm{GJ} / \mathrm{t}$ [73], and an average annual pellet diffusion rate of $14.5 \%$ starting in 2020. Furthermore, we suppose that after 2030 no more fuel oil will be used, and after 2036 neither will petroleum. Therefore, we assume that after 2036, only dry gas and residual wood pellets are consumed along with the pellets up to 2050. We are planning to stop using fuel oil by 2030 and petroleum coke by 2036 so that only dry gas will be consumed together with wood pellets by 2050; however, after 2036, dry gas will continue to be replaced until its share decreases to $0.1 \%$ by the end of the period.

In artisanal mezcal factories, we propose to replace a proportional part of the firewood used in the agave heart cooking and the mezcal distillation processes with briquettes from agave bagasse using existing boilers. To produce a litre of mezcal would be needed 15 to $20 \mathrm{~kg}$ on a wet basis, considering that the briquettes are impregnated with alcohols that can increase its efficiency when used as fuel [74]. We suggest that all firewood used should come from forest residues, then we can consider its emissions to be carbon neutral. In addition, we are proposing a model where briquettes production involves a third party collecting, processing, making the briquettes, and selling them at a preferential price to the mezcal factory [75]. Moreover, we assume that $17 \mathrm{GJ} / \mathrm{t}$ is the calorific value of agave bagasse briquettes [76], and aim an annual fuelwood substitution rate of $17.8 \%$ from 2019 to 2050 . 
The use of pellets from forest residues to replace LPG in dairy companies is suggested, considering a calorific value of wood waste pellets of $17.5 \mathrm{GJ} / \mathrm{t}$ [64]. Our prospective scenario put forward the introduction of pellets in 2019 with a replacement AAGR of $18.2 \%$ up to 2050. His fuel substitution implies a technological replacement of LPG gas boilers to pellet-based boilers [68]. At the end of the period, we expect the installation of 1591 biomass-based boilers in this niche.

In the craft breweries niche, our scenario proposes to use its more voluminous byproduct, the spent grain [77], as an alternative fuel to replace fossil fuels [77,78]. Following [79], we assume that for every $100 \mathrm{~L}$ of beer, we will have $20 \mathrm{~kg}$ of spent barley grain. Furthermore, to densify the spent grain, we consider its conversion into pellets [70]. According to [70], these pellets have a moisture content between $15 \%$ and $25 \%$ and a calorific value of $13.7 \mathrm{MJ} / \mathrm{kg}$; we consider introducing. the spent grain pellets will in 2020 with a replacement AAGR of $15.5 \%$ up to 2050. As in the mezcal niche, we suggest a business model for producing pellets that involves a third party collecting, processing, making the spent grain pellets, and selling them at a preferential price to the craft brewery.

The scenario also takes into consideration the following assumptions. First, the installation of 179 SBF-based boilers in breweries that currently have similar devices or whose production capacities make their implementation possible. Second, the biomassbased boilers for the dairy and craft beer niches have an efficiency of $93 \%$, a 30 years lifetime, a biomass consumption of $12 \mathrm{~kg} / \mathrm{h}$, a boiler investment cost of $2070 \mathrm{USD}$, and an O\&M cost of 103.5 USD [80].

Table 4 presents the characteristics of the SBFs utilization options by niche in the industrial sector.

Table 4. Characteristics of SBFs end-use options by niche.

\begin{tabular}{|c|c|c|c|c|c|}
\hline Niche & End-Use & Process & Biomass Inputs & SBFs Shape & Technology \\
\hline Brick kilns & \multirow{3}{*}{$\begin{array}{c}\text { Heat } \\
\text { generation }\end{array}$} & Brick firing & Forest residues & Firewood & \multirow{2}{*}{$\begin{array}{c}\text { MK2 oven } \\
\text { Conventional } \\
\text { boilers }\end{array}$} \\
\hline Limekilns & & Calcination & Forest residues & Pellets & \\
\hline Artisanal mezcal & & $\begin{array}{l}\text { Pineapple cooking } \\
\text { Distillation }\end{array}$ & Agave bagasse & Briquettes & Conventional oven \\
\hline Dairy products & $\begin{array}{c}\text { Steam } \\
\text { generation }\end{array}$ & $\begin{array}{c}\text { Pasteurization } \\
\text { Process heat } \\
\text { Maceration }\end{array}$ & Forest residues & Pellets & Biomass boiler \\
\hline Craft beer & & $\begin{array}{l}\text { Wort boiling } \\
\text { Sterilization and cleaning }\end{array}$ & Spent barley grain & Pellets & Biomass boiler \\
\hline
\end{tabular}

Source: Own elaboration.

\section{Results}

\subsection{Energy and Environmental Results of the Baseline Scenario (BS)}

According to the results obtained, the energy demand in the BS of the studied niches of the industrial sector will grow at an AAGR of 2.9\%, going from 6164 TJ in 2018 to 15,310 TJ in 2050 (See Figure 1). This result emphasizes that LPG energy demand increases an AAGR $5.7 \%$, followed by diesel that grows $4.1 \%$, fuel oil, petroleum coke, and dry gas will grow $4.0 \%$. In contrast, firewood grows only $2.1 \%$, while consumption of waste oils, plastics, and other energy will decrease at an annual rate of $1.4 \%$.

In the energy consumption structure in 2050, firewood will contribute $40.1 \%$, dry gas with $36.7 \%$, LPG with $8.1 \%$, fuel oil with $8.0 \%$, petroleum coke $4.3 \%$, oils and other energy sources $1.0 \%$, plastics $0.6 \%$ and $0.1 \%$ diesel.

Based on the estimated trends in energy consumption, the total CGHG emissions in 2050 could be 1.9 times higher than those emitted in 2018, going from $0.49 \mathrm{MtCO}_{2 \mathrm{e}}$ to $0.93 \mathrm{MtCO}_{2 \mathrm{e}}$; this increase is related to a significant rise in fossil fuels consumption and continuing firewood consumption levels with a non-renewability factor of $34 \%$ (Figure 2). 


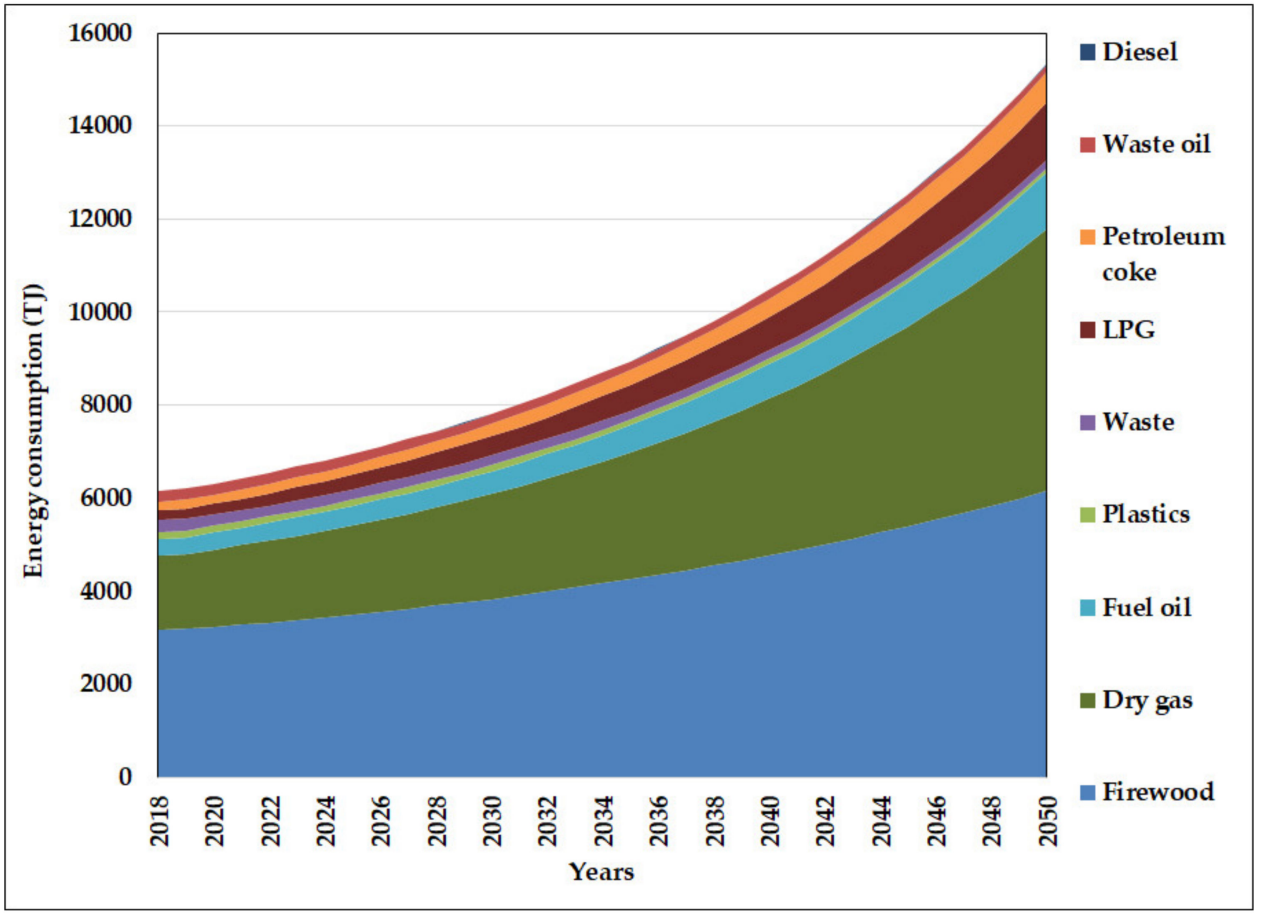

Figure 1. Energy consumption per fuel in the baseline scenario BS in Mexico's studied industrial SBFs niches from 2018-2050. Source: Own elaboration.

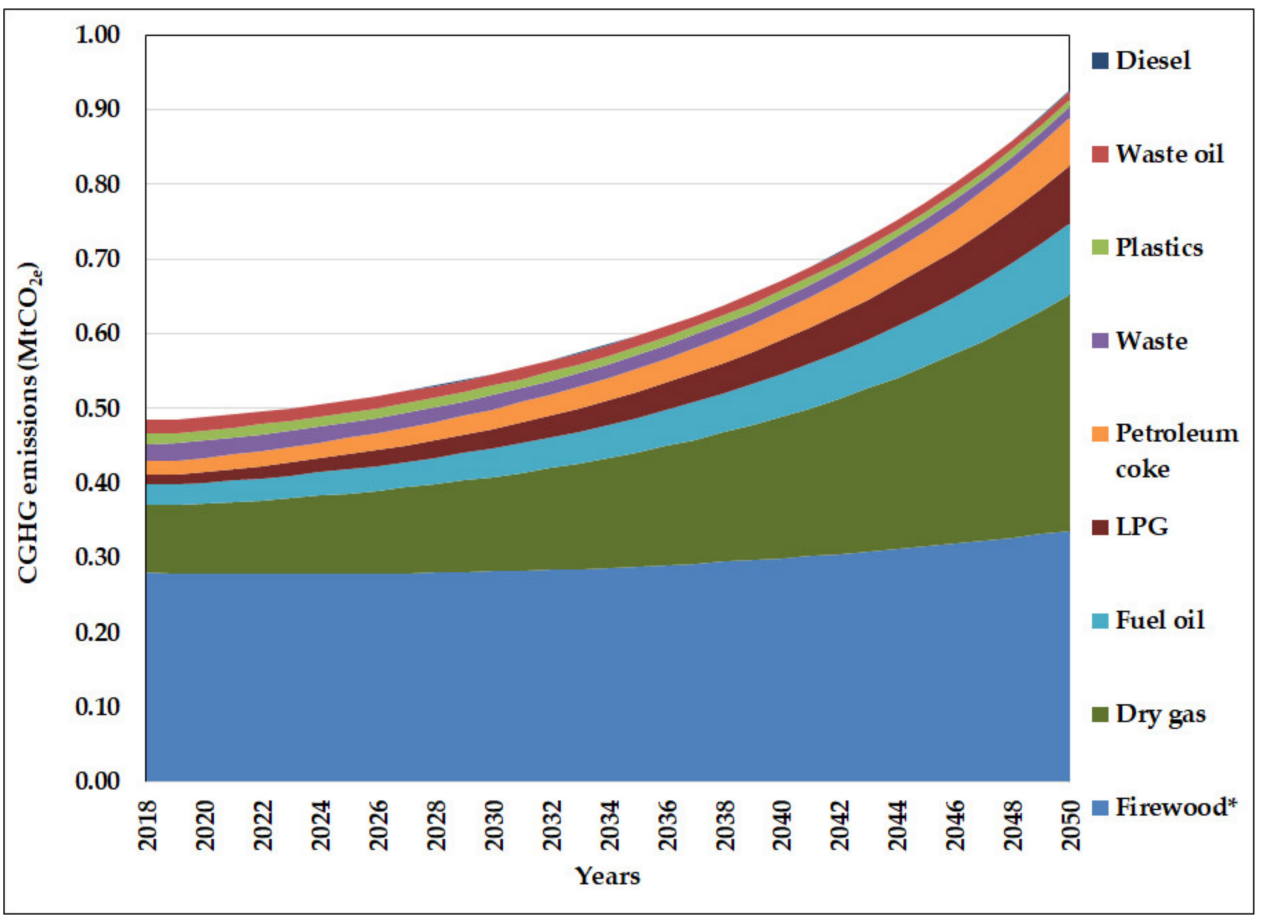

Figure 2. CGHG Emissions fuel in the BS of the studied niches of SBFs in the Mexican industrial sector, 2018-2050. * Firewood with a non-renewability factor of 34\% [57]. Source: Own elaboration.

\subsection{Energy and Environmental Results of the Alternative Scenario (AS)}

Figure 3 shows the energy consumption in the AS, established at 14,666 TJ by the year 2050, which represents $4.2 \%$ less energy consumption compared to the BS for that same year. However, the energy consumption structure changes significantly in 2050: renewable wood $30.9 \%$, pellets $21.4 \%$, briquettes of agave $9.4 \%$, and pellets of spent barley grain $0.3 \%$. While in fossil fuels consumption, dry gas represents $32.7 \%$, followed by LPG and diesel 
with $5.3 \%$ and $0.1 \%$, respectively. As a result, the AS presents a cumulative consumption of $177,884 \mathrm{TJ}$ of SBFs and 113,387 TJ of fossil fuels representing a 32\% decrease in fossil fuel consumption compared to the BS.

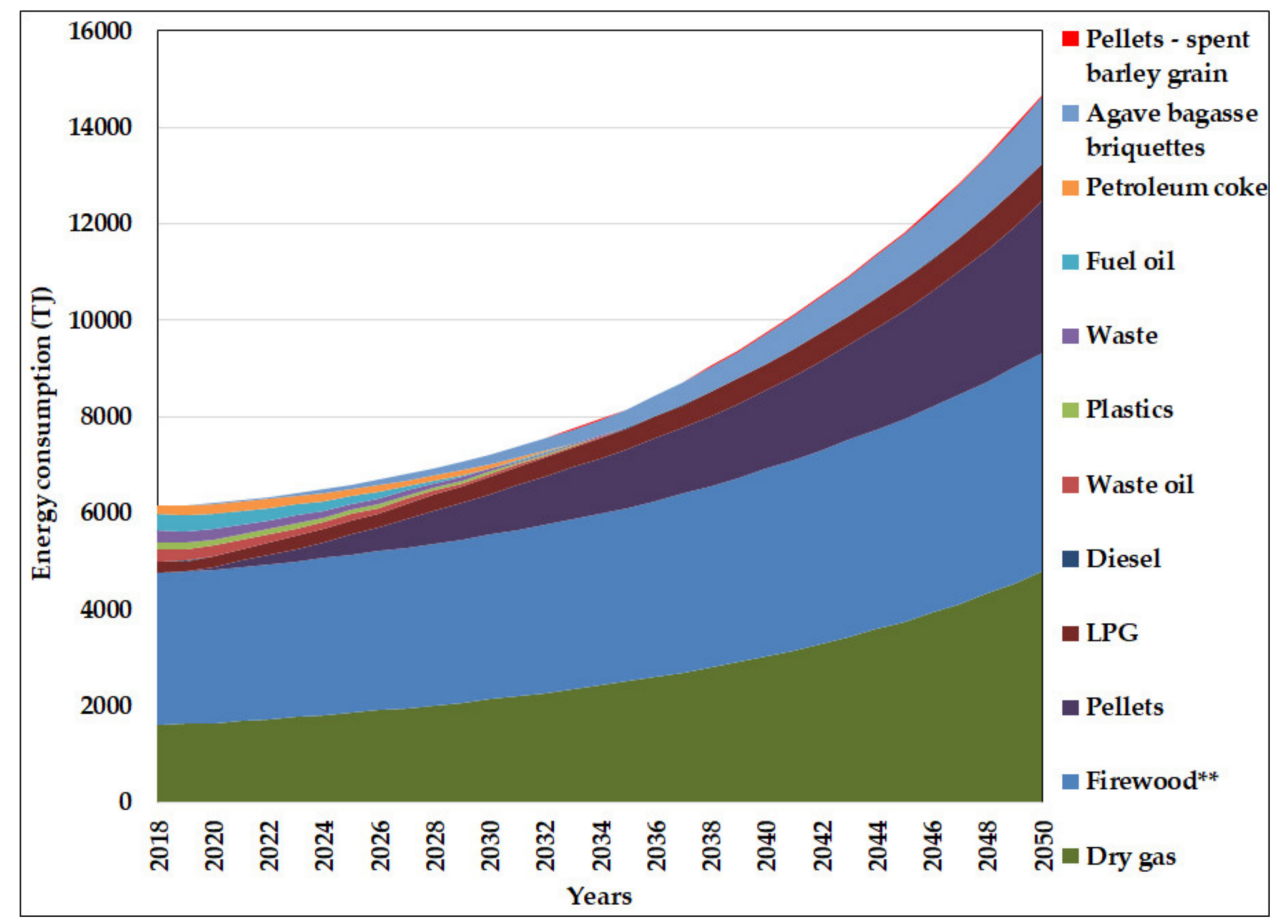

Figure 3. Energy consumption per fuel in the alternative scenario AS in Mexico's studied industrial SBFs niches from 2018-2050. ** Renewable residual firewood. Source: Own elaboration.

It is worth mentioning that in brick kilns SMEs, there was a reduction in energy consumption of $18,330 \mathrm{TJ}$, especially firewood, throughout the period, due to replacing traditional kilns with more efficient technologies, which represents a decrease of $22 \%$ compared to BS. In contrast, in limekilns SMEs, the fossil energy consumption is reduced by $36,505 \mathrm{TJ}$, which means a $28 \%$ fossil fuels decrease related to the BS, while in the SMEs of artisanal mezcal, the avoided consumption of fossil fuels is 15,027 TJ, which means a reduction of $19 \%$ compared to the BS. Finally, in craft breweries SMEs, the avoided consumption of fossil fuels is $4481 \mathrm{TJ}$, representing a $26 \%$ reduction compared to the BS, and finally, dairy SMEs avoid fossil fuels consumption by 536 TJ, representing $15 \%$ compared to the BS of the niche.

Figure 4 shows the evolution of emissions CGHG in the AS in the period 2018-2050, where CGHG emissions from plastics, litter, diesel, fuel oil, petroleum coke, and waste oils cease around the year 2036; however, dry gas and natural gas emissions continue to grow to reach around $0.32 \mathrm{MtCO}_{2 \mathrm{e}}$ by 2050. Thus, the AS presents cumulative CGHG emissions of $6.78 \mathrm{MtCO}_{2 \mathrm{e}}$, representing a reduction of $62.7 \%$ of the emissions of the BS.

As presented in Table 5 , in global terms, the five mitigation options considered have a cumulative mitigation potential of $13.88 \mathrm{MtCO}_{2 \mathrm{e}}$, representing a reduction of $62.7 \% \mathrm{com}$ pared to the total cumulative emissions in the base scenario during the analysis period. Our results show that heat production in brick kilns, limekilns, and mezcal factories contribute to this reduction with $37.6 \%, 13.7 \%$, and $14.4 \%$, respectively, and steam production in the dairy and craft beer industry $1.4 \%$ and $0.2 \%$, respectively. 


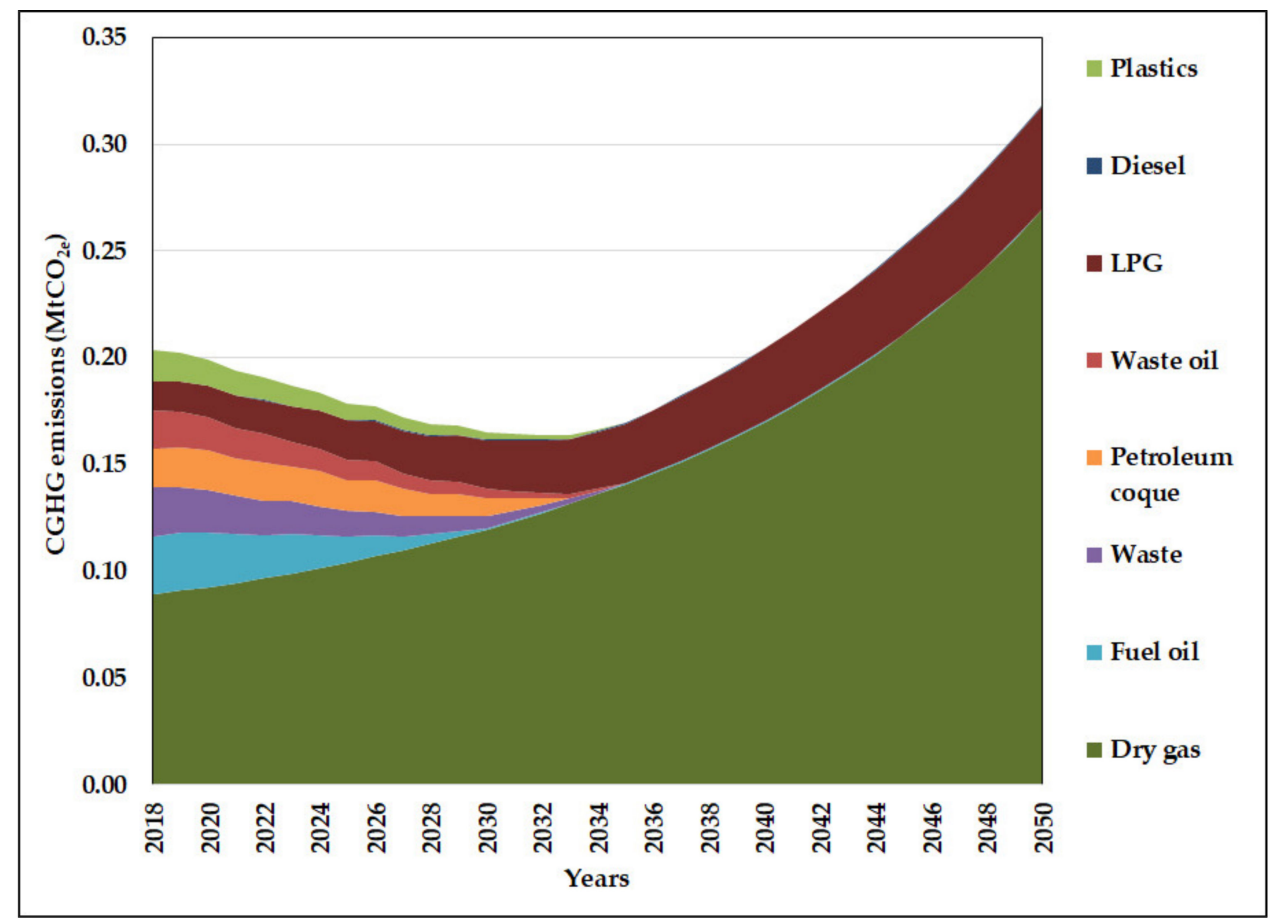

Figure 4. CGHG emissions fuel in the Stage Alternative niches of SBFs studied in the Mexican industrial sector, 201 in August -2050. Source: Own elaboration.

Table 5. Energy and environmental results of the studied niches of the Mexican industrial sector.

\begin{tabular}{cccccc}
\hline \multirow{2}{*}{ Niche } & $\begin{array}{c}\text { Fossil Energy } \\
\text { Avoided }\end{array}$ & $\begin{array}{c}\text { Accumulated } \\
\text { Avoided Fossil } \\
\text { Energy }\end{array}$ & $\begin{array}{c}\text { CGHG Avoided } \\
\text { Emissions in }\end{array}$ & $\begin{array}{c}\text { Cumulative } \\
\text { Avoided CGHG } \\
\text { Emissions }\end{array}$ & $\begin{array}{c}\text { Emissions } \\
\text { Avoided } \\
\text { Compared to BS }\end{array}$ \\
\cline { 2 - 6 } & $\mathbf{2 0 5 0}$ & $\mathbf{2 0 1 8 - 2 0 5 0}$ & $\mathbf{2 0 5 0}$ & $\mathbf{2 0 1 8 - 2 0 5 0}$ & $\mathbf{2 0 1 8 - 2 0 5 0}$ \\
\hline Brick kilns & $\mathbf{( T J )}$ & $\mathbf{( T J )}$ & $\mathbf{( M t C O}_{\mathbf{2 e}} \mathbf{)}$ & $\mathbf{( M t C O}_{\mathbf{2 e}} \mathbf{)}$ & $\mathbf{\%}$ \\
Limekilns & 644.7 & $18,330.6$ & 0.10 & 2.77 & $37.6 \%$ \\
Artisanal Mezcal & 1373.0 & $36,505.1$ & 0.20 & 2.97 & $13.7 \%$ \\
Dairy products & 442.5 & $15,027.4$ & 0.17 & 0.28 & $14.4 \%$ \\
Craft breweries & 49.8 & 535.8 & 0.03 & 0.04 & $1.4 \%$ \\
Total & 5204.7 & 4481.4 & 0.003 & 13.88 & $0.2 \%$ \\
\hline
\end{tabular}

${ }^{*}$ Considering firewood with a $100 \%$ renewability factor. Source: Own elaboration.

\subsection{Economic Results by Industrial SME Niche}

Table 6 shows the economic results of every studied SMEs niche. In three niches, there are economic benefits; these are dairy, beer, and artisanal mezcal. The cost-benefit of dairy is -4.05 million USD (MUSD from now on) as a consequence of the low investment cost of biomass boilers (0.21 MUSD) and the significant savings in fossil fuels (-4.25 MUSD), which means a negative mitigation cost $\left(-14.30 \mathrm{USD} / \mathrm{tCO}_{2 \mathrm{e}}\right)$. The cost-benefit of craft breweries is negative ( -0.46 MUSD) due to the low investment cost of biomass boilers (0.06 MUSD) and the significant savings in fossil fuels (-0.46 MUSD), which represents a negative mitigation cost $\left(-10.68 \mathrm{USD} / \mathrm{tCO}_{2 \mathrm{e}}\right)$. Finally, the cost-benefit of artisanal mezcal is also negative ( -2.89 million USD) and equal to fossil fuel savings, allowing a negative mitigation cost, i.e., a benefit $\left(-0.98 \mathrm{USD} / \mathrm{tCO}_{2 \mathrm{e}}\right)$.

In contrast, two niches show a positive cost-benefit and subsequently a mitigation cost; these are brick and limekilns. The cost-benefit of the brick industry niche is 77.59 MUSD due to the high investment cost of efficient kilns (83.25 MUSD) related to the savings in O\&M and fuels, mainly firewood, equal to -5.66 MUSD, which results in a mitigation 
cost of 9.99 USD/ $\mathrm{tCO}_{2 \mathrm{e}}$. Similarly, the cost-benefit of the limekilns niche is $55.90 \mathrm{MUSD}$, this time due to the high cost of biofuels in comparison to fossil fuels in the BS, which represents a mitigation cost of $19.74 \mathrm{USD} / \mathrm{tCO}_{2 \mathrm{e}}$.

Table 6. Cost-Benefit and Mitigation Cost at studied SMEs niches of the Mexican industrial sector.

\begin{tabular}{cccccc}
\hline \multirow{2}{*}{ Niche } & Investment & O\&M & Fuel & Cost-Benefit & Mitigation Cost \\
\cline { 2 - 5 } & \multicolumn{5}{c}{ Million USD (MUSD) } \\
\hline Brick kilns & 83.25 & -0.21 & -5.46 & 77.59 & USD/tCO 2e \\
Limekilns & - & - & 55.90 & 55.90 & 9.99 \\
Dairy products & 0.21 & - & -4.25 & -4.05 & -14.30 \\
Craft breweries & 0.06 & - & -0.46 & -0.40 & -10.68 \\
Artisanal mezcal & - & - & -2.89 & -2.89 & -0.98 \\
\hline
\end{tabular}

Source: Own elaboration.

In Figure 5, the $X$-axis represents the total emission mitigation potential. In the $Y$-axis, the mitigation cost, three niches show a negative mitigation cost, but with relatively low mitigation potentials and two niches present positive mitigation costs, although with high mitigation potentials. First, observe that the niche that mitigates the most emissions is the brick industry with $7.77 \mathrm{MtCO}_{2 \mathrm{e}}$ with a positive mitigation cost of $9.99 \mathrm{USD} / \mathrm{tCO}_{2 \mathrm{e}}$ second is the artisanal mezcal niche that has a lower mitigation potential of $2.97 \mathrm{MtCO}_{2 \mathrm{e}}$, but a favourable mitigation cost of $-0.98 \mathrm{USD} / \mathrm{tCO}_{2 \mathrm{e}}$. Third, we find the limekilns niche mitigation potential is $2.83 \mathrm{MtCO}_{2 \mathrm{e}}$, but with a positive mitigation cost of $19.74 \mathrm{USD} / \mathrm{tCO}_{2 \mathrm{e}}$; fourth the dairy niche with a potential of $0.28 \mathrm{MtCO}_{2 \mathrm{e}}$ and a negative mitigation cost of $-14.30 \mathrm{USD} / \mathrm{tCO}_{2 \mathrm{e}}$ and, fifth, the craft beer niche with a small mitigation potential of $0.04 \mathrm{MtCO}_{2 \mathrm{e}}$ and a convenient mitigation cost of $-10.68 \mathrm{USD} / \mathrm{tCO}_{2 \mathrm{e}}$.

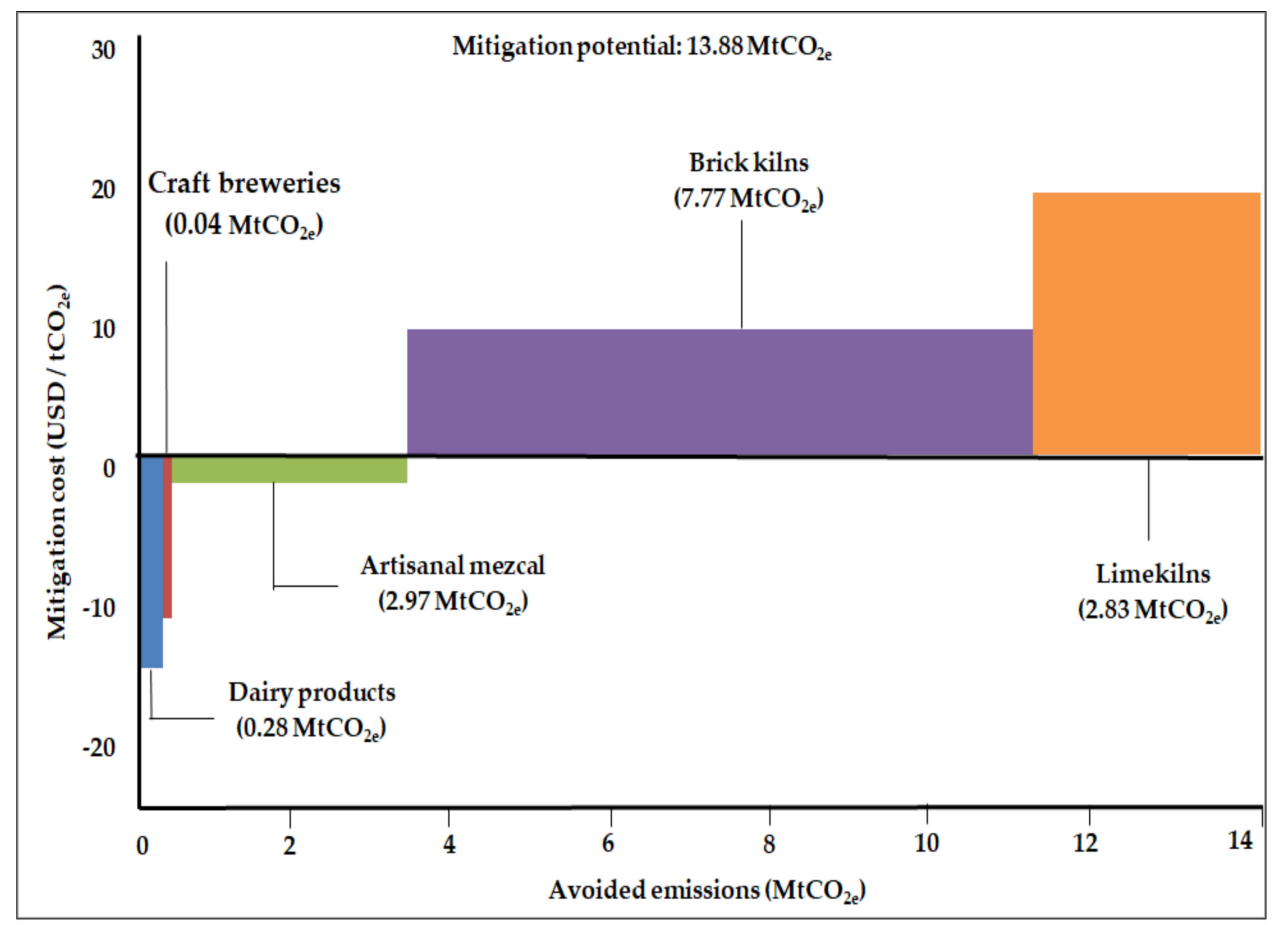

Figure 5. Mitigation costs and avoided emissions by each industrial SMEs niche during the 2018-2050 period. Source: Own elaboration.

From the above, we infer that it would be reasonable to start mitigation actions by implementing quickly through adequate regulation and standards. First, using SBFs in niches that present negative mitigation costs (artisanal mezcal, dairy products, and craft breweries). In addition, establish in parallel and progressively, incentives and adequate 
financing policies to accelerate SBFs' use in niches that have positive mitigation costs (lime and brick kilns) but that have significant mitigation potential.

\section{Conclusions}

We propose an alternative scenario considering SBFs utilization in SMEs in the Mexican industrial sector, which promotes the diversification of the Mexican energy matrix with existing biomass inputs not previously valorised. In this study, we present the analysis and results of the implementation of SBFs made from agricultural and forest biomass residues as inputs in SMEs. Thus, we provide an option to convert residues into green businesses to mitigate climate change and show the possibility of modernizing the SMEs with technology and sustainable energy inputs that allow them greater efficiency. In the case of the brick-making niche, for example, a decrease in energy consumption is generated due to the replacement of traditional kilns by modern and efficient MK2 kilns, allowing firewood to be used more efficiently in addition to harnessing renewable firewood that substitutes non-sustainable firewood, always associated with a non-renewability factor. SBFs also allow for an energy diversification that enables fossil fuel substitution and reduces price and supply risks in the energy portfolio of the studied niches. Thus, in the limekilns niche, we propose the total substitution of fuel oil and petroleum coke and partial substitution of diesel, LPG, and dry gas by wood pellets.

Furthermore, we consider installing SBF boilers (pellets) instead of LPG boilers in the dairy and craft beer niches. Specifically, in the dairy factories niche, we propose a partial LPG substitution by wood pellets, and in the craft breweries niche, we suggest a total substitution of diesel and fuel oil, and partial substitution of LPG, by spent barley grain pellets. Additionally, we suggest discontinuing fossil fuels in the brick kilns niche, eliminating waste oils, plastics, and solid waste for energy purposes. Finally, in the artisanal mezcal niche, we propose a partial substitution of traditional firewood consumption by agave bagasse briquettes, interchanging traditional firewood with a modern SBFs.

The niches that mitigate the most emissions are the brick kilns niche $\left(7.77 \mathrm{MtCO}_{2 \mathrm{e}}\right)$ and the limekilns niche $\left(2.83 \mathrm{MtCO}_{2 \mathrm{e}}\right)$. However, their costs are higher than their benefits due to the relatively high costs of MK2 technology, and pellets, respectively; therefore, we suggest that adequate ecological and financial incentives are required to implement them. In contrast, the niches with negative mitigation costs are the artisanal mezcal niche (with a high mitigation potential of $2.97 \mathrm{MtCO}_{2 \mathrm{e}}$ ) and the dairy and craft beer niches (that mitigate less, $0.28 \mathrm{MtCO}_{2 \mathrm{e}}$ and $0.04 \mathrm{MtCO}_{2 \mathrm{e}}$, respectively). Moreover, their negative mitigation costs (originated from fossil fuels avoided cost) make them easier to implement through regulatory measures and adequate standards established for sustainable production and uses.

Finally, the proposal to use commercial SBFs (pellets, briquettes, and sustainable firewood) contributes to generating formal markets with adequate distribution channels to supply the analysed industrial niches. This proposal also encourages the creation of green jobs in agricultural and forestry areas and give value to inputs that have not been valued until now, such as spent barley grain, agave bagasse, and residual firewood generated in situ in rural and forestry areas; their valorisation also contributes to social development.

Supplementary Materials: The following are available online at https:/ /www.mdpi.com/article/1 0.3390/en14206560/s1, Table S1: Fuel Prices; Table S2: Fuel Emission Factors.

Author Contributions: Conceptualization, J.M.I.-S.; methodology, J.M.I.-S., F.M., O.R.-C. and G.K.G.A.; software, O.R.-C., L.L.-P. and C.Á.-E.; validation, J.M.I.-S., F.M., O.R.-C., L.L.-P., G.K.G.-A. and C.Á.-E.; formal analysis, O.R.-C., L.L.-P.; investigation, O.R.-C., L.L.-P., J.M.I.-S., F.M., G.K.G.-A. and C.Á.-E.; resources, J.M.I.-S. and F.M.; data curation, O.R.-C. and L.L.-P.; writing-original draft preparation, J.M.I.-S., F.M., O.R.-C., L.L.-P., G.K.G.-A. and C.Á.-E.; writing-review and editing, J.M.I.-S., F.M., O.R.-C., L.L.-P., G.K.G.-A. and C.Á.-E.; visualization, O.R.-C. and L.L.-P.; supervision, J.M.I.-S., F.M., G.K.G.-A.; Project Administration, F.M. and J.M.I.-S.; Funding Acquisition, F.M. and J.M.I.-S. All authors have read and agreed to the published version of the manuscript. 
Funding: This research was funded by SENER- CONACYT Project 2014-05-246911 and also DGAPA UNAM PSPA scholarship for a Jorge M. Islas S. 2021 sabbatical stay at CIE-MAT-Spain.

Institutional Review Board Statement: Not applicable.

Informed Consent Statement: Not applicable.

Data Availability Statement: Not applicable.

Acknowledgments: Authors thank María de Jesús Pérez Orozco for her technical support in the search and data collection. We also thank Claudia Carretta Beltran for her valuable revision of the English language. Finally, thanks are due to the consultancy XENERCO for their technical and administrative support in obtaining the information inputs.

Conflicts of Interest: The authors declare no conflict of interest.

\section{References}

1. U.S. Energy Information Administration (EIA). International Energy Outlook 2019 with Projections to 2050. Available online: https: / / www.eia.gov/outlooks/ieo/pdf/ieo2019.pdf (accessed on 24 August 2021).

2. International Energy Agency (IEA). $\mathrm{CO}_{2}$ Emissions from Fuel Combustion. Available online: https://www.iea.org/reports/co2emissions-from-fuel-combustion-overview (accessed on 24 August 2021).

3. International Energy Agency (IEA). Renewable Energy for Industry. Available online: http://admin.indiaenvironmentportal.org .in/files / file/RenewableEnergyforIndustry.pdf (accessed on 24 July 2021).

4. International Energy Agency (IEA). Global Bioenergy Consumption by Type of Source and Sector. 2018. Available online: https:/ / www.iea.org/data-and-statistics/charts/global-bioenergy-consumption-by-type-of-source-and-sector-2018 (accessed on 24 July 2021).

5. Malico, I.; Nepomuceno Pereira, R.; Gonçalves, A.C.; Sousa, M.O. Current Status and Future Perspectives for Energy Production from Solid Biomass in the European Industry. Renew. Sustain. Energy Rev. 2019, 112, 960-977. [CrossRef]

6. European Pellets Council. Report Pellets 2019. Available online: https:/ / epc.bioenergyeurope.org/bioenergy-europe-pellet-repo rt-2019/ (accessed on 23 March 2021).

7. U.S. Energy Information Administration (EIA). Wood and Wood Waste. Available online: https://www.eia.gov/energyexplaine d/biomass / wood-and-wood-waste.php (accessed on 22 July 2021).

8. International Energy Agency (IEA). World Energy Balances. Available online: https://www.oecd-ilibrary.org/energy/data/ieaworld-energy-statistics-and-balances/world-energy-balances_data-00512-en (accessed on 15 July 2021).

9. International Energy Agency (IEA). World Energy Statistics 2018; OECD: Paris, France, 2018; ISBN 9789264301269.

10. Mahato, N.; Sharma, K.; Sinha, M.; Baral, E.R.; Koteswararao, R.; Dhyani, A.; Cho, M.H.; Cho, S. Bio-Sorbents, Industrially Important Chemicals and Novel Materials from Citrus Processing Waste as a Sustainable and Renewable Bioresource: A Review. J. Adv. Res. 2020, 23, 61-82. [CrossRef] [PubMed]

11. Tauro, R.; García, C.A.; Skutsch, M.; Masera, O. The Potential for Sustainable Biomass Pellets in Mexico: An Analysis of Energy Potential, Logistic Costs and Market Demand. Renew. Sustain. Energy Rev. 2018, 82, 380-389. [CrossRef]

12. Fazzino, F.; Mauriello, F.; Paone, E.; Sidari, R.; Calabro, P. Integral Valorization of Orange Peel Waste through Optimized Ensiling: Lactic Acid and Bioethanol Production. Chemosphere 2021, 271, 129602. [CrossRef] [PubMed]

13. Martins, L.C.; Monteiro, C.C.; Semedo, P.M.; Sá-Correia, I. Valorisation of Pectin-Rich Agro-Industrial Residues by Yeasts: Potential and Challenges. Appl. Microbiol. Biotechnol. 2020, 104, 6527-6547. [CrossRef]

14. Jeong, D.; Park, H.; Jang, B.; Ju, Y.; Shin, M.; Oh, E.; Lee, E.; Kim, S. Recent Advances in the Biological Valorization of Citrus Peel Waste into Fuels and Chemicals. Bioresour. Technol. 2021, 323, 124603. [CrossRef] [PubMed]

15. Zema, D.A.; Calabrò, P.S.; Folino, A.; Tamburino, V.; Zappia, G.; Zimbone, S.M. Valorisation of Citrus Processing Waste: A Review. Waste Manag. 2018, 80, 252-273. [CrossRef]

16. Navarro Pineda, F.S.; Equihua-Sánchez, M.; Grande-Acosta, G.K.; Sacramento Rivero, J.C.; Islas-Samperio, J.M.; Bonales Revuelta, J.; Musule, R.; García, C.A.; Manzini, F. Assessment of the Environmental and Economic Performance of Heat Generation from Orange Peels and Sugarcane Straw. Bioenerg. Res. 2021. [CrossRef]

17. Fernández Baca, M. La Energía de La Biomasa. Ing. Ind. 1994, 12, $21-29$.

18. International Renewable Energy Agency (IRENA). Solid Biomass Supply for Heat and Power: Technology Brief; International Renewable Energy Agency: Abu Dhabi, United Arab Emirates, 2019; p. 51. ISBN 978-92-9260-107-2.

19. Islas, J.; Manzini, F.; Masera, O.; Vargas, V. Solid Biomass to Heat and Power. In The Role of Bioenergy in the Emerging Bioeconomy; Elsevier: Amsterdam, The Netherlands, 2019; pp. 145-177.

20. Honorato-Salazar, J.A.; Sadhukhan, J. Annual Biomass Variation of Agriculture Crops and Forestry Residues, and Seasonality of Crop Residues for Energy Production in Mexico. Food Bioprod. Process. 2020, 119, 1-19. [CrossRef]

21. Hu, J.; Lei, T.; Wang, Z.; Yan, X.; Shi, X.; Li, Z.; He, X.; Zhang, Q. Economic, Environmental and Social Assessment of Briquette Fuel from Agricultural Residues in China-A Study on Flat Die Briquetting Using Corn Stalk. Energy 2014, 64, 557-566. [CrossRef]

22. Sims Ralph, E.H. The Brilliance of Bioenergy: In Business and in Practice; Taylor and Francis: Abingdon, UK, 2013 ; p. 328. 
23. Secretaría de Energía (SENER). Reporte de Inteligencia Tecnológica Biocombustibles Sólidos. Available online: https:/ /www.gob. $\mathrm{mx} / \mathrm{cms}$ /uploads/attachment/file/306072/Inteligencia_Tecnologica_BCS_220218.pdf (accessed on 25 August 2021).

24. De Lucas Herguedas, A.I.; del Peso Taranco, C.; Rodrígez García, E.; Prieto Paniagua, P. Biomasa, Biocombustibles y Sostenibilidad; Centro Tecnológico Agrario y Agroalimentario: Palencia, Spain, 2012; Volume 13, p. 109, ISBN 978-84-931891-5-0.

25. Diario Oficial de la Federación (DOF). Programa Especial Para El Aprovechamiento de Energías Renovables. Available online: http:/ / www.dof.gob.mx/nota_detalle.php?codigo=5342501\&fecha=28/04/2014 (accessed on 27 August 2021).

26. Xu, J.; Chang, S.; Yuan, Z.; Jiang, Y.; Liu, S.; Li, W.; Ma, L. Regionalized Techno-Economic Assessment and Policy Analysis for Biomass Molded Fuel in China. Energies 2015, 8, 13846-13863. [CrossRef]

27. United Nations Industrial Development Organization (UNIDO). Renewable Energy in Industrial Applications. Available online: https:/ /www.solarthermalworld.org/sites/default/files/unido_renewables_industrial_applications.pdf (accessed on 28 August 2021).

28. Masera, O.R. La Bioenergía En México. Un Catalizador Del Desarrollo Sustentable; Mundi-Prensa México: Mexico City, Mexico, 2006; ISBN 968-7462-42-6.

29. Johnson, T.; Alatorre, C.; Romo, Z.; Feng, L. México: Estudio Para La Disminución de Emisiones de Carbono (MEDEC); Primera Edición; Banco Internacional de Reconstrucción y Fomento/Banco Mundial: Washington, DC, USA, 2009; ISBN 978-958-8307-75-6.

30. Ehrig, R.; Behrendt, F. Co-Firing of Imported Wood Pellets-An Option to Efficiently Save $\mathrm{CO}_{2}$ Emissions in Europe? Energy Policy 2013, 59, 283-300. [CrossRef]

31. García, C.A.; Masera, O.; Riegelhaupt, E.; Ghilardi, A.; Skutsch, M.; Islas, J.; Manzini, F. Sustainable Bioenergy Options for Mexico: GHG Mitigation and Costs. Renew. Sustain. Energy Rev. 2015, 43, 545-552. [CrossRef]

32. León, P.; Vidal, F.; Rodríguez, T.; Castro, A.; Arrazola, I.; García, A.; Martínez, S.; Hernández, R.; Castro, M. Estudio de La Cadena de Valor Del Sector Ladrillero Del Estado de Jalisco. Available online: https://semadet.jalisco.gob.mx/sites/semadet.jalisco.gob .mx/files/estudio_de_la_cadena_de_valor_del_sector_ladrillero_del_estado_de_jalisco.pdf (accessed on 20 June 2020).

33. García, C.A.; Riegelhaupt, E.; Masera, O. Escenarios de Bioenergía En México: Potencial de Sustitución de Combustibles Fósiles y Mitigación de GEI. Rev. Mex. Física 2013, 59, 93-103.

34. Islas, J.; Manzini, F.; Masera, O. A Prospective Study of Bioenergy Use in Mexico. Energy 2007, 32, 2306-2320. [CrossRef]

35. Instituto Nacional de Geografía y Estadística (INEGI). Comunicado de Prensa Num. 617/20. El INEGI Presenta Resultados de La Segunda Edición Del ECOVID-IE y Del Estudio Sobre Demografía de Los Negocios 2020. Available online: https: / /inegi.org.mx /contenidos/saladeprensa/boletines/2020/OtrTemEcon/ECOVID-IE_DEMOGNEG.pdf (accessed on 28 July 2021).

36. Bouille, D.; Carpio, C.; Sbroiavacca, N.D.; Dubrobsky, H.; Nadal, G.; Lallana, F.; Landavery, R.; Pistonesi, H.; Planchú, J.; Recalde, M.; et al. Propuesta de Instrumentos Para Facilitar Medidas de Eficiencia Energética En El Sector Industrial de México. Available online: https:/ / www.gob.mx/conuee/acciones-y-programas / propuesta-de-instrumentos-para-facilitar-medidas-de-eficienc ia-energetica-en-el-sector-industrial-de-mexico (accessed on 13 July 2021).

37. Secretaría de Energía (SENER). Balance Nacional de Energía 2018. Available online: https://www.gob.mx/cms/uploads/attac hment/file/528054/Balance_Nacional_de_Energ_a_2018.pdf (accessed on 10 April 2020).

38. Secretaría de Energía (SENER). Sistema de Información Energética. Available online: http:/ / sie.energia.gob.mx (accessed on 13 September 2020).

39. CONADESUCA-SAGARPA. Reducción Del Consumo de Petróleo y Generación de Energía Eléctrica En Los Ingenios. Available online: https://www.gob.mx/cms/uploads/attachment/file/515516/Boletin_Tecnico_Informativo_Enero_2016.pdf (accessed on 18 September 2020).

40. Alvarado Machuca, S.V.; Álvarez Sánchez, M.E.; Maldonado Torres, R.; Sánchez Velez, A.S. Consumo de leña en México: Hábitos de uso, problemática asociada y alternativas sostenibles de solución. In Agroforestería Para la Conservación de los Recursos Naturales y Productividad; Universidad Autónoma Chapingo: Texcoco, Mexico, 2018.

41. Arias-Chalico, T. Situación Actual y Escenarios Para El Desarrollo Del Biogás En México Hacia 2024 y 2030. Available online: http://rembio.org.mx/newsite/wp-content/uploads/2020/11/Situacion-actual-y-escenarios-para-el-desarrollo-del-bi ogas-en-Mexico.pdf (accessed on 25 August 2021).

42. Arias-Chalico, T. Tecnologías de Aprovechamiento de Biomasa Forestal Para Energía En México Viabilidad y Recomendaciones Generales Para Su Selección. Available online: https:/ / energypedia.info/index.php?title=File:GIZ_Tecnologías_biomasa_forestal 2015.pdf\&page=1 (accessed on 18 October 2020).

43. Durán-García, M.D.; Weber, B.; Jiménez-García, J.A. Análisis de Sustentabilidad Del Empleo de BCS Para Calor de Proceso. Rev. de Desarro. Urbano y Sustentable 2019, 5, 1-12. [CrossRef]

44. Instituto Nacional de Estadística y Geografía (INEGI). Encuesta Mensual de La Industria Manufacturera (EMIM) 2007-2019. Base 2008. Available online: https:/ / www.inegi.org.mx/programas/emim/2007/ (accessed on 20 June 2020).

45. Asociación de Cerveceros Artesanales de México (ACERMEX). Reporte de La Industria Cervecera Independiente Mexicana 2018. Available online: http:/ / acermex.org/wp-content/uploads/2020/01/Reporte-de-la-Industria-.-Acermex-2actua.pdf (accessed on 20 November 2020).

46. Consejo Regulador de Mezcal. Informe Estadístico 2020. Available online: https:/ /www.gob.pe/institucion/pronacej/informes -publicaciones/1758100-informe-estadistico-2020 (accessed on 13 December 2020).

47. Bhattacharyya, S.C. Energy Economics: Concepts, Issues, Markets and Governance; Springer: London, UK, 2011. 
48. Grande-Acosta, G.; Islas-Samperio, J. Towards a Low-Carbon Electric Power System in Mexico. Energy Sustain. Dev. 2017, 37, 99-109. [CrossRef]

49. Instituto Nacional de Ecología y Cambio Climático (INECC). Estudio Para Desarrollar Un Modelo de Negocio Piloto En Ladrilleras Artesanales, Para Reducir Emisiones de Contaminantes Climáticos de Vida Corta y Gases de Efecto Invernadero, Así Como Mejorar La Calidad de Vida de Los Actores Clave. Available online: https:/ /www.gob.mx/cms/uploads/attachment/file/4933 91/Ladrilleras_versi_n_final-2019.pdf (accessed on 25 August 2021).

50. Guerrero Gómez, G.; Espinel Blanco, E.; Sánchez Acevedo, H.G. Análisis de Temperaturas Durante La Cocción de Ladrillos Macizos y Sus Propiedades Finales. Tecnura 2017, 21, 118. [CrossRef]

51. Instituto Nacional de Ecología y Cambio Climático (INECC). Apoyo a la Iniciativa de Planificación Nacional sobre Contaminantes Climáticos de Vida Corta en México. Available online: https://www.gob.mx/cms/uploads/attachment/file/40813/2013_snap_ mexico_esp.pdf (accessed on 25 August 2021).

52. Henriques, M.F.; Valença Schwob, M.R.; Pinto Rodrigues, J.A. Manual de Eficiencia Energética En La Industria Ladrillera; Instituto Nacional de Tecnología: Rio de Janeiro, Brazil, 2015.

53. Cárdenas, B.; Aréchiga, U.; Munguía, J.L.; Márquez, C.; Campos, A. Evaluación Preliminar Del Impacto Ambiental Por La Producción Artesanal de Ladrillo: Eficiencia Energética y Calidad Del Aire; Universidad Autónoma Metropolitana: Mexico City, Mexico; Instituto Nacional De Ecología: Mexico City, Mexico, 2012.

54. Cova Orozco, A.; Morales Zendero, L.A.; Ibáñez Sosa, G.; Ochoa Lomelin, A.; Leñero Ríos, M.; Camacho Zepeda, D.A.; Cornejo González, N.A.; Estrada Hernández, Á.; Camacho López, S. Proyecto de Aplicación Profesional (PAP). Available online: https:/ / rei.iteso.mx/bitstream/handle/11117/5219/Proyecto+ladrilleras.pdf?sequence=2 (accessed on 28 August 2020).

55. Climate Technology Centre \& Network. Horno MK2. Available online: https://www.ctc-n.org/sites/www.ctc-n.org/files/UNF CCC_docs/ref34x13_35.pdf (accessed on 30 September 2020).

56. Instituto Nacional de Ecología y Cambio Climático (INECC). Análisis de Mercado Del Sector de La Construcción y Proyecto Piloto a Nivel Región Basado En Un Portafolio de Políticas Con El Objetivo de Reducir Los Contaminantes Climáticos de Vida Corta, de Ladrilleras Artesanales En México. Available online: https://www.gob.mx/cms/uploads/attachment/file/253631/8 _CGCV_2016_Ana_lisis_de_Mercado_Ladrilleras_Artesanales_CDMEX.pdf (accessed on 25 August 2021).

57. Serrano Medrano, M.; Ghilardi, A.; Masera, O. Fuelwood Use Patterns in Rural Mexico: A Critique to the Conventional Energy Transition Model. Hist. Agrar. 2019, 77, 81-104. [CrossRef]

58. Durán Alca, J.C.; Mendoza Murillo, R. Influencia de La Sílice En El Proceso de Calcinación Para Reducir El Contenido de Requemado En El Óxido de Calcio; Universidad Nacional de San Agustín de Arequipa: Arequipa, Peru, 2017; p. 73.

59. Ministerio para la Transición Ecológica y el Reto Demográfico (MITECO). Fabricación de Cal (Emisiones de Proceso). Available online: https: / / www.miteco.gob.es/es/calidad-y-evaluacion-ambiental/temas/sistema-espanol-de-inventario-sei- /040614descarbonatac-fabric-cal_tcm30-429852.pdf (accessed on 25 August 2021).

60. Secretaría del Medio Ambiente y Recursos Naturales (SEMARNAT); Instituto Nacional de Cambio Climático (INECC). Componente 5: Medidas Para La Implementación Temprana Del Convenio de Minamata. Informe Final. Available online: https://www.gob.mx/cms/uploads/attachment/file/341246/Informe_Final_Compilado_Componente_5.pdf (accessed on 25 August 2021).

61. Diario Oficial de la Federación (DOF). Norma Oficial Mexicana NOM-070-SCFI-2016, Bebidas Alcohólicas-Mezcal-Especificaciones. Available online: https: / /dof.gob.mx/nota_detalle.php?codigo=5472787\&fecha=23/02/2017\&print=true (accessed on 25 August 2021).

62. Mezcal Oaxaca. Proceso y Producción Del Mezcal. Available online: http://www.mezcal-oaxaca.com/procesoyproducciondelm ezcal.html (accessed on 25 August 2021).

63. García, M.; Méndez, R. El Consumo de Leña En La Producción de Mezcal. El Caso de Santiago Matatlán, Oaxaca. Available online: http:/ / www.fao.org/3/AD096S/AD096S03.htm\#ch2 (accessed on 25 August 2021).

64. Diario Oficial de la Federación (DOF). Lista de Combustibles 2018 Que Se Considerarán Para Identificar a Los Usuarios Con Un Patrón de Alto Consumo, Así Como Los Factores Para Determinar Las Equivalencias En Términos de Barriles Equivalentes de Petróleo. Available online: https:/ / www.dof.gob.mx/nota_detalle_popup.php?codigo=5417918 (accessed on 25 August 2021).

65. Palma, F.; Pérez, P.; Meza, V. Diagnóstico de La Cadena de Valor Mezcal En Las Regiones de Oaxaca. Available online: http:/ / www.coplade.oaxaca.gob.mx/wp-content/uploads/2017/04/Perfiles/AnexosPerfiles/6.CVMEZCAL.pdf (accessed on 28 March 2020).

66. Servicio Nacional de Sanidad y Calidad Agroalimentaria (SENASA). Pasteurización. Available online: http://www.senasa.gob.a $\mathrm{r} /$ senasa-comunica/noticias/pasteurizacion (accessed on 25 August 2021).

67. Luluaga, S.; Nuñez, M. Guia de Elaboración de Quesos Artesanales. Available online: http://www.alimentosargentinos.gob.ar/c ontenido/procal/proyectospiloto/2009/2009_Lacteos_Tucuman_01_guiaQuesos.pdf (accessed on 25 August 2021).

68. Riva, G. Utilization of Renewable Energy Sources and Energy- Saving Echnologies by Small-Scale Milk Plants and Collection Centres. Available online: http:/ /www.fao.org/3/T0515E/T0515E00.htm (accessed on 25 August 2021).

69. Bleier, B.; Callahan, A.; Farmer, S.; Min, H. Craft Beer Production. Sr. Des. Rep. 2013, 53, $15-17$.

70. Sperandio, G.; Amoriello, T.; Carbone, K.; Fedrizzi, M.; Monteleone, A.; Tarangioli, S.; Pagano, M. Increasing the Value of Spent Grain from Craft Microbreweries for Energy Purposes. Chem. Eng. Trans. 2017, 58, 487-492. [CrossRef] 
71. Los Cervecistas. El Proceso de Fabricación de La Cerveza. Available online: https:/ /www.loscervecistas.es/el-proceso-defabrica cion-de-la-cerveza/ (accessed on 23 July 2021).

72. Instituto Nacional de Ecología y Cambio Climático (INECC). Rutas de Instrumentación de Las Contribuciones Nacionalmente Determinadas En Materia de Mitigación de Gases y Compuestos de Efecto Invernadero (GyCEI) Del Sector Industria (Cemento, Acero, Calero y Azucarero) En México, Como Insumo Para La Sexta Comunicación Nacional de Cambio Climático. Available online: https:/ / www.gob.mx/cms/uploads/attachment/ file/462290/5_Industria_Intensiva_V2.pdf (accessed on 25 August 2021).

73. Gobierno de la República. Lista de Combustibles 2020 Que Se Considerarán Para Identificar a Los Usuarios Con Un Patrón de Alto Consumo, Así Como Los Factores Para Determinar Las Equivalencias En Términos de Barriles Equivalentes de Petróleo. Available online: https:/ /www.gob.mx/cms/uploads/attachment/file/302306/Lista_de_combustibles_2018.pdf (accessed on 26 November 2020).

74. Chavez, G. Uso de Bagazo de La Industria Mezcalera Como Materia Prima Para Generar Energía. Ingenierías 2010, 13 , 8-16.

75. Herrera-Camacho, J.; Modesto Sánchéz, N.; Martínez-Palacios, A. Prospectiva Estratégica Para El Aprovechamiento Del Bagazo Residual de Agave Generado al Producir Mezcal En Michoacán. In Proceedings of the X Congreso Internacional de Gestión, Calidad y Competitividad Empresarial, Morelia, Michoacán, Mexico, 8-9 October 2015; pp. 1536-1569.

76. Transformación Carbón Energía. Resultado de Las Pruebas Con Briquetas de Biomasa de Agave. Available online: https: / / carbondiversionamericalatina.files.wordpress.com/2011/11/resultado-laboratorio-briquetas-tce-espac3b1ol.pdf (accessed on 25 August 2021).

77. Jackowski, M.; Niedźwiecki, Ł.; Jagiełło, K.; Uchańska, O.; Trusek, A. Brewer’s Spent Grains—Valuable Beer Industry by-Product. Biomolecules 2020, 10, 1669. [CrossRef] [PubMed]

78. Mussatto, S.I.; Dragone, G.; Roberto, I.C. Brewers' Spent Grain: Generation, Characteristics and Potential Applications. J. Cereal Sci. 2006, 43, 1-14. [CrossRef]

79. Reinold, M.R. Manual Prático de Cervejaria; ADEN Editora e Comunicações: Sao Paulo, Brazil, 1997.

80. Made in China. Pellet Biomasa Generador de Vapor Para La Industria de Cerveza. Available online: https:/ / es.made-in-china.c om/co_oukerg/product_Biomass-Pellet-Steam-Generator-for-Beer-Industry_ehnhrihry.html (accessed on 25 August 2021). 